\title{
COMPETITIVE BIDDING IN THE SALE OF PUBLIC UTILITY BONDS
}

THE completion of the Securities and Exchange Commission's hearings ${ }^{1}$ on the proposal to compel public utilities ${ }^{2}$ to sell their securities through competitive bidding ${ }^{3}$ points sharply the current question in public utility finance. ${ }^{*}$ To the suggestion that utility bonds ${ }^{5}$ be sold only after the submission of competitive bids by potential purchasers as a means of reducing underwriter's fees and ending banking monopolies, investment bankers have noted an emphatic exception. ${ }^{6}$ Although the issue has become the subject of extensive and bitter dispute, ${ }^{7}$ adequate analysis of the underlying problem is still needed. ${ }^{8}$ It is the contention of this Comment that today underwriters' fees

1. The hearings were held during January and February, 1941. They received wide publicity, being the first public discussion ever conducted by the SFC on any question of policy. See, e.g., N. Y. Times, Jan. 29, 1941, p. 23, col. 8; Feb. 6, 1941, p. 31, col. 8.

2. The hearings related only to utilities subject to the Public Utility Holding Company Act of 1935. 49 Stat. 803 (1935), 15 U.S. C. $\$ 79$ (Supp. V 1939).

3. The Public Utilities Division has issued a report favoring competitive bidding: The Problem of Mandaining Arar's-Length Bargaining and Competitive Co:nitions in the Sale and Distribution of Secunitirs of Registered Public Uituiti Holding Cosmpantes and Their Subsimiaries (SEC Pub. Util. Div, 1940), hereinafter cited as Pub. UTIL. REPORT.

4. Commissioner, now Mr. Justice, Douglas posed the issue in the famous Bond Club speech in 1937. Dovglas, Dexrocracr and Finaxce (1940) 32. Other recommendations have followed. Commissioner Walker of the FCC recommended the FCC he given power to require that the American Tel. \& Tel. Co. system sell its securities through competitive bidding. Proposed Report Telephone Investigntron (FCC 1938) 705. See also the dissenting opinion of Commissioners Eicher and Henderson in Consumer's Power Co., 6 S. E. C. 444, 501, 503 (1939) ; Otis \& Co.'s open letter to the ICC recommending competitive bidding for all railroad bonds, N. Y. Herald-Tribune. Dee. 21, 1940, p. 26, col. 1; and attempts of Halsey, Stuart \& Co. to inject a competitive element into recent bond issues, N. Y. Times, Jan. 15, 1941, p. 31, col. 5; N. Y. Times, Jan. 22, 1941, p. 29, col. 2; N. Y. Times, Feb. 6, 1941, p. 31, col. 4.

5. This Comment is limited to competitive bidding in the sale of publie utility bonds. Competitive bidding in the sale of equity securities is of less importance and materials for discussion are relatively scarce.

6. MicCintock (Harriman Ripley \& Co.), Competitive Bindixg fún New Issues of Securities (1939); Stanley (President, Morgan, Stanley \& Co.), Competrune. BidDing for New Issues of CoRporate Securities (1939); Coksely (President, Investment Bankers Association), A REpLY (1940).

7. See notes 4 and 6 supra. See editorial comments: N. Y. Herald-Tribune, Dee. 23, 1940, p. 18, col. 2; N. Y. Herald-Tribune, Jan. 25, 1941, p. 10, col. 2; N. Y. Times, Jan. 31, 1941, p. 18, col. 2.

8. For general discussions see Pub. Utrl. Reront; Abrams, Fallacy of Compctitive Bidding for Utility Securitics (1937) 19 P. U. Fort. 414, 476; Elgen, I'alue of Competitive Biddings for Utility Sccuritics (1937) 19 P. U. Font. 723; Report of Spce. Comm. on Pub. Util. Finance (1938) 415, Axs. Procendisgs N.r. Ass':: of R. R. \& UtTl Connoros; id. (1939) 184; Moulton and Assochates, Capital Expansion, Eas-

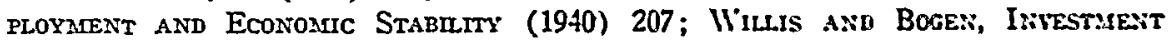
Banking (1936) 428. See also note 6 sipra. 
are excessive, that they stem from the existence of more or less informal monopolistic practices among investment bankers, so far untouched by the regulating techniques of the Commission, and that the effects of these practices can be successfully curtailed only by a system of competitive bidding.

Present system of financing. The traditional method of selling utility bonds involves a sale by the issuing corporation to a syndicate of investment bankers called underwriters, at a price determined by private negotiation with the principal underwriter, who is usually the corporation's banker and the originator of the business. ${ }^{0}$ The underwriters receive as compensation for the risk assumed, for dealer's commission, and for management services, a fee which at present averages $\$ 2$ per $\$ 100$ of principal, or two "points." 10 But when the risk involved in underwriting a utility bond issue is slight and the services rendered by dealers in selling the bonds to a receptive public are largely perfunctory, these fees may be excessive.

There is little risk in underwriting a utility bond issue today since it is highly improbable the bonds will not find a ready market. It is a truism that since 1930 new private capital expansion has halted. Normal investment outlets have dried up and savings which formerly provided risk capital for new enterprise have turned to more conservative investments, resulting in a pile up of great reservoirs of capital in banks and other institutions now desperately seeking suitable outlets for their billions. ${ }^{11}$ But these outlets are few, and the result has been a tremendous demand for securities of the high investment rating enjoyed by the average utility bond. Insurance companies, revealing an insatiable appetite for high grade bonds, have even purchased large blocks of bonds directly from the corporations issuing them. ${ }^{12}$ Moreover, as the great bulk of present day utility bond financing is refunding, ${ }^{13}$ former holders frequently provide an almost automatic market for new issues. Under

9. Dewing, Financial Policy of Corporations (3d ed. 1934) Bk. V, cc. 8, 9, 10 ; Moulton, op. cit. supra note 8 , c. X.

10. The present average fee includes seven-eighths of a point for risk, seven-eighths for dealers, and one fourth as the principal underwriter's management fee.

11. The situation is described in Moulton, op. cit. supra note 8, c.c. I-IV, X. As to insurance companies and their investments, see ANN. PROC. OF THE ASs'N OF LIFE INSURANCE PREsidents (1939) 108-119. Abandonment of the present "passive" financial machinery in favor of a system of government-subsidized "capital credit" has been suggested. See Berle, New Directions in the New World (1940) c. V; Hitchcock, Twentieth Century Capitalism (March 1941) Harper's, 428.

12. Rodgers, Purchase by Life Insurance Companies of Sectrities Prizately Offered (1939) 52 Harv. L. Rev. 773; Selected Statistics on Securities and on Exchange MARKETS (SEC 1939) 45. In 1940, exciuding railroad financing, these private placements alone accounted for $56 \%$ of all corporate bond and note emissions, while in 1939 they amounted to $43.7 \%$. N. Y. Times, Jan. 2, 1941, p. 49, col. 2.

13. Moulton, op. cit. supra note 8 , at 36 ; Shultz and Caine, Financtal Development of the United States (1937) 708; 152 Com. \& Fin. Chron. (March 8, 1941) 1494. 
such conditions payment of substantial sums for the "risk" assumed by an underwriter can hardly be justified.1\% Likewise, large payments to dealers as commissions for services rendered in selling the bonds are objectiunable. In 1920 it was possible for the ICC to approve substantial underwriting fees on the ground that an issue could be sold only in small blocks to scatterel individual investors, a process requiring an elaborate and expensive distributing organization. ${ }^{15}$ Today there is no comparable problem of security distribution and the task of selling the bonds of an average utility invulves little more than the effort required to telephone a local bank or insurance company. ${ }^{16}$ Yet, because of the absence of competitive motives for reductiun of financing charges, underwriters and dealers are compensated as though they performed a highly valuable and unique function.

The reasons for conditions under which such practices have flourished are not unduly elusive. In the first place, the important investment bankers that dominate the nation's corporate financing ${ }^{17}$ do not compete among themselves. ${ }^{18}$ Rather, they have preferred to permit each of their number to monopolize the business of financing certain corporations, a practice nurtured by the peculiar ethics of the profession of investment banking. Once banker $X$ has handled $Y$ corporation's financing other bankers will not offer their services in connection with new financing by $Y$ until it is clear that there has been a "break" between $X$ and $Y .{ }^{10}$ On occasion this non-competitive tradition has been crystallized by agreements among bankers allotting to one another rights to participate in the financing of future issues of corporations

14. See note 96 infra.

15. For this reason the ICC approved an underwriting fee of $3 \% 2$ points. Bonds of the N. Y. Central R. R., 65 I. C. C. 172 (1920). But the Commission noted that absence oi competitive bidding made it difficult to determine whether the fee was reasonable.

16. Two recent analyses of the distribution of certain high grade bond issues demonstrated that $\$ 8.4 \%$ of the bonds went to institutional purchasers. Hcarings bejore the Temporary National Economic Committec, 76th Cong., 3d Sess. Pt. 24 (1940) 12,70s (hereafter cited as Hcarings).

17. Hearings 12,688-12,711. Thirty-eight banking firms managed $91 \%$ of all issues registered between 1934 and 1939 . Of this amount, $57 \%$ was managed by six New York City firms while 14 other New York firms and 18 firms outside of New York managed $21 \%$ and $12 \%$ respectively. Hearings 12,691 . The degree of concentration is greater as to high-grade bonds. Morgan, Stanley \& Co. alone managed four-fifths of all first grade registered bond issues managed by 38 leading firms in the United States. Hearings 12,710 .

18. Brandets, Other Peoples Money (1914) 45; Thorp and Assoctates, Ecosomic Problears in a Changing Worto (1939) 604.

19. See note 18 supra. On one occasion Glore, Forgan \& Co. refused a request to become principal underwriter because it had been a nember of the syndicate headed by Lehman Bros., which had underwritten the company's prior bond issue. Glore, Forgan \& Co. apparently felt that it could not properly disregard the other banker's prior claim to the business. Hearings 12,469-12,471. On other occasions Kuhn, Loeb \& Co. recorded its desire not to compete for a financing proposition when it developed that another firm had an historical claim to the business. Hearings 12,487, 12,503 . 
assumed to be within the sphere of influence of one of their number.20 Arrangements of this character seem to be agreements not to compete similar to those held illegal at common law, ${ }^{21}$ but never having been challenged, they have not incurred judicial disapproval.

In the second place, in spite of management's clear-cut obligation to share-holders to sell the securities at the best price obtainable, the managements of utility corporations have not attempted to sell their securities on a competitive basis, thus greatly strengthening the restraining effect of the practices of the investment banking business. This failure of management to inject a competitive element into security sales is not a fortuitous development, but the achievement of financial groups which have an interest in restricted competition. Instrumental in persuading management to shun competition are certain beliefs held by investment bankers. Most familiar are the tenets that a long-continued relationship between banker and corporation has an actual value for the corporation,,22 and that changing bankers, or shopping around among various bankers to obtain the best price for an issue, are indications that the credit standing of the corporation is unsound. ${ }^{23}$ Although they have been frequently used, it has never been established that these arguments embody more reality than myth. In the words of Commissioner, now Mr. Justice, Douglas: ". . . the economic tutility of continuity of banking relationships is of unestablished value to any one except the banker." 24 It is axiomatic that the credit of an issuer rests on judgments based upon its balance sheet, its earning prospects, and the competence of its management, rather than upon the minute details of its distribution of securities. ${ }^{25}$

20. The classic example is the "Library Agreement" of 1920 by which sharcs in the future financing of the American Telephone \& Telegraph system werc allotted among J. P. Morgan \& Co., Kidder, Peabody \& Co., and other bankers. Hearings 11,864-11,875 et seq. Another famous instance is the financing of the Chicago Union Station Co. Hearings 11,426-11,478. In both cases these non-competitive agreements were effectively carried out. Hearings 12,234, Exhib. No. 1587 at 11,641. See also Hearings 12,353, 12,472. Arrangements of this character are commonly referred to as "frozen accounts"; the bankers involved are considered to have "proprietary interests" in the financing. Hearings $11,515,11,570,11,865$.

21. Handler, Cases on Trade Regulation (1937) cc. III, IV.

22. Charles Adams, Trustee of Utilities Power \& Light Co., testified that there was an "intangible value" in having one firm continue to handle a company's financing. SEC Holding Company Act Release No. 2001, April 2, 1940, at 15. See STANLEY, op. cit. supra note 7.

23. See Newport Electric Corp., 4 S. E. C. 999, 1014 (1939); SEC Holding Company Act Release No. 2001, April 2, 1940, at 15. For a successful departurc from these inlibiting concepts consider recent financing by Shell Union Oil Corp. Hearings 12,625$12,66+$.

24. Douglas, op. cit. supra note 4, at 37. Sec also BRANders, op. cit. supra note 18 , at 44. Long-continued banker-issuer relationships do not seem to have been of much "value" for investors or issuers, in the light of the unbalanced capital structures, dividend arrears, and bankruptcies in the public utility industry.

25. Pub. Util. Report 28. 
Arguments of this character are often unnecessary, however, because underwriters are frequently in a position directly to require that there be no competitive element in a corporation's financing. By controlling the siurces of capital, ${ }^{26}$ by exacting contracts which grant an option on future financing, $=\pi$ and by utilizing interlocking directorates ${ }^{28}$ and stock ownership, ${ }^{20}$ bankers have been able to influence the amount of their remuneration and to insure the maintenance of their privileged status as principal underwriters. This was especially true in public utility finance prior to the Public Utility Hulding Company Act of 1935, when banker control through stock ownership was common $^{30}$ and was generally accompanied by monopolistic abuses ${ }^{31}$ resulting in rich benefits for the bankers involved. In brief, the system of non-cumpetitive privately negotiated sales has been a fruitful source of unreasunable gain for bankers, in which the public interest that utilities be financed at minimum cost has been ignored. ${ }^{32}$ On this record the system of private negotiation has little claim to a place in the sale of utility bonds.

Attempts to regulate the present systcm. The sale of securities by private negotiation with a single banker has not been altogether unregulated. The Securities and Exchange Commission, the Federal Power Commission, and many state utility commissions have some measure of authority over the terms and conditions upon which public utilities issue securities, ${ }^{33}$ while the

26. FTC Report on Utility Corporatioss, Sen. Doc. No. 92, Part 72-A, 70th Cong., 1st Sess. (1935) 75.

27. Hcarings 12,546, 12,854-12,860.

28. See testimony in Hearings, 12,356 .

29. FTC Report on Utility Corporitions, Sen. Due. No. 92, Part 72-A, 7uth Cong., 1st Sess. (1935) 75-81, 111-116, 145-151.

30. See note 29 supra. For a specific instance of control and the unreasonable charges which may result therefrom see Safe Harbor Water Power Curp., Licensee, 1 Fed. Power Conrar. Rep. 230 (1935); 1 Fed. Power Coarar. Rep. 367 (1937).

31. In the Report of the National Power Policy Comnittee the situation was summarized: "Fundamentally the holding-company problem always has been, and still is, as much a problem of regulating investment bankers as a problem of regulating the power industry." Nit. Power Policy Coans. Report, H. R. Doc. No. 137, 74th Cong., 1st Sess. (1935) 6. See H. A. Byllesby \& Co., 6 S. E. C. 639 (1940).

32. Consider the statement of SEC Commissioner Henderson on the finaneing of A. T. \& T.: "That the capital was provided at the lowest cost and in a manner most in the public interest is a question which cannot be answered. For at no time during this entire period (1906-1939) did the bankers or the company consider any alternative method of financing than that of direct dealings with a single banking group." Hcarings 11, \$29. See also Proposed Report Telephone Ixvestigatiox (FCC 1938) 506.

33. Sections 6(b) and 7 of the Public Utility Holding Company Act [ 49 Srar. 803 (1935), 15 U. S. C. $\$ 79$ (Supp. V 1939)] and $\$ 204$ of the Federal Water Power Act [49 STAT. 838 (1935), 16 U.S. C. $\$ 791$ (Supp. V 1939)] give the SEC and the Federal Power Commission broad powers over security issues of public utilities. The jurisdiction of the FPC is linited to security issues not regulated by state utility commissions. In practice the Commission has assumed jurisdiction unless a utility's security issue is supervised both by the state or states in which it operates and the state in which it is incorporated. Application Tennessee Electric Power Co. (1936) 1 Fed. Power Cousss. 
Interstate Commerce Commission has exclusive juriscliction over railroad financing. ${ }^{34}$ It is the function of these administrative bodies to protect the public interest by requiring utilities to sell their securities on the best possible terms, and to this end they have attempted to reduce underwriting charges to a minimum. ${ }^{35}$ In general these commissions, including the SEC, have determined the reasonableness of a given fee by comparing it with others charged in selling issues of comparable size and quality, where similar conditions have prevailed. ${ }^{36}$ Thus the usual fee, established by non-competitive private negotiation and therefore misleading as a criterion, has become the touchstone for determining the propriety of underwriting charges in new issues. ${ }^{37}$ Acceptance of this norm may be explained in part by absence of administrative vigor, ${ }^{38}$ lack of statutory power, ${ }^{30}$ or reluctance of commissions to interfere with managerial discretion ${ }^{40}$ in deference to judicial pronouncements that commissions are not the financial managers of utilities. ${ }^{41}$ In addition, com-

Rep. 668 (1940); In re Otter Tail Power Co. (1939) 1 Fed. Power Coms. Rep. 794 (1940).

At present 17 states fail to provide explicitly for regulation of utility security isstes. For an analysis of the various statutory powers which have been granted sce the chart iin Bonbright \& Co., A Survey of Laws on Pub. Util. Comm. Reg. in the United States (1930). Since 1930 several states have enacted statutes regulating utility securities, among them Oregon, Pennsylvania, and Washington. ORE. Code ANN. (Supp. 1935) §61-289, 291 ; Pa. Stat. Ans. (Purdon, 1940) tit. 66, §§ 1241-1243; Wasir. Rev. Stat. ANn. (Remington, 1940) \$10439-2, 4. A model statute for state regulation of utility securities is suggested in Report of Spec. Comm. on Pub. Util. Finance, Ann. Proc. Nat. Ass'N of R. R. \& Util. Comm'rs (1938) 419.

34. 41 StAT. 494 (1920), 49 U. S. C. \$20(a) (1934).

35. For a brief summary of the public's interest in low underwriting fees see ANN. Proc. Nat'l Ass'n R. R. \& Util. Comm'rs (1939) 184. See also Investigntion of TELEPHONE INDUSTRY (FCC 1939) 593.

36. The burden of proving the reasonableness of a fee may be imposed on managcment and underwriters. The administrative operations involved are discussed in Jersey Central Power \& Light Co., 33 P. U. R. (N.s.) 207 (1940). The SEC follows a similar procedure. PUb. Util. RePORT D-15.

37. Since the Holding Company Act is designed to prevent lack of economy in the raising of capital, an argument that a fee is "reasonable" solely becausc usual is not persuasive. For the applicable cases see Pub. UTIL. RePort D-14.

38. Insufficient appropriations and political interference have on occasion prevented effective administration. Mosher and Crawford, Public Utility Regulation (1933) cc. V, VI. Berle speaks of the "decay" of the ICC in New Directions in A NEw WORLD (1940) 93.

39. See note 33 supra.

40. See concurring opinion of Commissioner Woodlock in Chicago, Milwatuec \& St. Paul Equipment Trust Series D, 99 I. C. C. 682, 690, 691 (1925). Contra: Consumer's Power Co., 6 S. E. C. 444, 460 (1939) (Commissioner Frank); Mosher ano Crawrowu, op. cit. supra note 39 , at c. VII; 1 Sharpiran, The Interstate Commence Commission (1931) 4.

41. See Missouri ex rel. S. W. Bell Telephone Co. v. Public Service Comm., 262 U. S. 276, 289 (1923) ; People ex rel. Delaware \& Hudson Co. v. Stevens, 197 N. Y. 1, 90 N. E. 60 (1909); Blue Mountain Consol. Water Co. v. Public Service Comm., 125 Pa. Super. 1, 8, 189 Atl. 545, 548 (1937). 
missions have feared that requiring departure from habitual banking practice might seriously interfere with the success of new financing operations. ${ }^{\text {2 }}$ Even more compelling has been the reluctance of regulatory bodies to penalize a utility by holding up an issue at the crucial period when market conditions are favorable, merely because the underwriting fee may be improper. ${ }^{43}$ But whatever the cause for its retention, reliance on the standard of the usual fee is responsible for the maintenance of underwriting fees at their present high level.

A second approach to the problem is based on the assumption that excessive charges arise from the existence of control relationships such as interlocking directorates between banker and issuer, or banker ownership of the issuing corporation's stock. ${ }^{44}$ The Public Utility Holding Company let of 1935 , expressly designed to eliminate such evils, ${ }^{\text {to }}$ contains the most complete expression of this policy. Under Section 17(c) holding companies and subsidiaries are not permitted to have a representative of any financial institution as officer or director except where the SEC finds such relationships are not detrimental to the public interest. Under Section $12(\mathrm{~g})$ no "affiliate" of a utility may enter into a contract with that utility without complying with rules or orders to be made by the SEC regarding the maintenance of com-

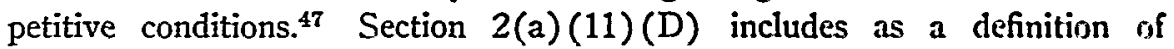
affiliate:

any person ... (standing) . . . in such relation to such specified company that there is liable to be such an absence of arm's-length

42. The ICC has been especially influenced by this consideration. See Bonds of Chicago Union Station Co., 86 I. C. C. 529, 532 (1924).

43. Kansas Elec. Power Co., 1 S. E. C. 891 (1936) ; Axn. Proceemmiss Xitr. Ass:: of R. R. AND UTIL. Comprrs (1939) 185.

44. Section 10 of the Clayton Act specifically provides that when a common carrier is linked to a prospective purchaser by an interlocking directorate, or by a substantial stock ownership by its directors, its securities should be sold through competitive bidding. 38 SтAт. 734 (1914), 15 U. S. C. $\$ 20$ (1934). Also it is illegal for an officer or director of a common carrier to receive anything of value in respect of the sale of securities by such carrier. 41 Stat. 496 (1920), 49 U. S. C. $\$ 20$ (a) (12) (1934). Section 305 of the Federal Power Act applies similar rules to public utilities. $4 y$ Sr.ur. 838 (1935), 16 U. S. C. \$ 791 (Supp. V 1939). Likewise, the states have specially supervised transactions where there is a control relationship. For example, the Illinois commission has jurisdiction over contracts between a utility and an "affiliated interest," defined as a $10 \%$ voting interest or any person which the conmission may determine is aiftully exercising any substantial influence over the policies of a utility. IL.L. Axw. Sr.t. I SmithHurd 1940) c. 111 2/3, §8(a).

45. 49 Stat. 803 (1935), 15 U. S. C. $\$ 79$ (Supp. V 1939).

46. Section 1 (b) (5) specifically declares that lack of econumy in raising capital is a detriment to the public interest.

47. At one stage the Act read "competitive bidding." 79 Cosc. Rec 10,557 (1935). The language was changed to broaden its scope. 79 (uNco. Rec: S931 (1935). See alsu original language in $\$ 7(f)$ providing for competitive bidding. 79 Cosic. REs. 10,305 (1935). 
bargaining between them as to make necessary . . . that such person shall be subject to the obligations . . . imposed in this title upon affiliates of a company. ${ }^{48}$

Thus any underwriter found by the Commission to be an affiliate under this clause is subject to the special rule-making powers conferred by Section $12(\mathrm{~g})$.

The SEC did not invoke the broad language of Section 2(a)(11)(D) at once, preferring to begin by employing Section $7($ d) (4) which directs the Commission to require that fees be reasonable. The even tenor of this policy, however, was interrupted by the Kansas Electric Pozver ${ }^{40}$ case where the underwriting fee was unreasonable by the Commission's standard and, in addition, there was no satisfactory explanation for the automatic selection as underwriters of bankers holding stock in the company's parent. The Commission finally approved the company's declaration to issue the bonds by a vote of three to two, but both majority and minority opinions warned the financial community that the Commission strongly disapproved such relationships between underwriters and issuers, and that other cases involving an absence of arm's-length bargaining might induce the Commission to require competitive bidding. The problem was narrowed in the subsequent San Anton:o: ${ }^{50}$ and Blackstone Valley Gas ${ }^{51}$ cases, where, although the fees met the SEC's standard of reasonableness, the underwriters had ignored the Kansas case warning and retained ties with issuers. In these cases the Com* mission again intimated its disapproval of interlocks but dicl not refuse the applications by making an adverse finding under Section 7 (d)(4), since it felt bound by previous decisions to hold these fees reasonable.

At this juncture several paths were open. The Commission could have revised its standard of reasonableness in the light of the discussion above; ;ia it could have required competitive bidding $;^{53}$ it could have evaded the ques-

48. The power of the Commission to use $\S 2(a)(11)(D)$ was limited by $\$ 2(b)$ which provided that no person should be deemed an "affiliate" under $\$ 2$ (a) (11)(D) unless the Commission, after appropriate notice and opportunity for hearing, has issued an order to that effect, the order not to be effective for 30 days. The other definitions of affiliate in $\$ 2(a)(11)$ depend on ownership of a specified percentage of stock.

49. 1 S. E. C. 891 (1936).

50. 3 S. E. C. 414 (1938). See also report of the Public Utilities Division of the SEC on "disorderly competition" in a recent San Antonio Co. issue. SEC Release, Mar. $12,1941$.

51. 4 S. E. C. 77 (1938). See also American Light \& Traction Co., 3 S. E. C. 969 (1938); Gulf States Util. Co., 3 S. E. C. 814 (1938). In considering SEC policy on reasonableness and affiliation certain finder's fee cases are relevant. West Penn Power Co., 3 S. E. C. 774 (1938); Connecticut Light \& Power Co., 4 S. E. C. 60 (1938); Connecticut Light \& Power Co., 5 S. E. C. 706 (1939); SEC Holding Company Act Release No. 2156, July 8, 1940. See Meck and Cary, Regulation of Corporate Finance and Management under the Public Utility Holding Company Aot of 1935 (1938) 52 Hasv. L. Rev. 216, 238.

52. See pp. 1072-75 supra.

53. The Commission was not obliged to choose between general competitive bidding or none at all. It could have proceeded from case to case, requiring competitive bidding 
tion on the ground the Act was not intended to penalize control relationships not economically dangerous; or it could have condoned the system of private negotiation, attempting to eliminate interlocks apart from any question of reasonableness of fees. The Commission finally adopted the last possibility, believing proper interpretation of the Act required it, and promulgated Rule $\mathrm{U}-12 \mathrm{~F}-2,{ }^{54}$ a regulation conclusively condemning financial affiliation even where underwriting charges were not found to be excessive. In substance the Rule incorporated the definition of affiliate set out in Section 2(a)(11)(D) and provided that no fee should be paid to any underwriter who was found to be an affiliate of the issuer within the meaning of the Rule, ${ }^{50}$ unless such underwriter had no more than a five per cent participation in the purchase of the issue, and would not receive compensation as managing underwriter. ${ }^{57}$ Even before the Commission attempted to apply the Rule where a finding of affiliation would be necessary, the Rule revealed grave weaknesses. On three occasions underwriters retained both interlocks and the power and prestige of principal underwriter, ${ }^{58}$ avoiding a contest on the affiliation question by restricting their participation to five per cent and receiving no management fee. ${ }^{59}$ Thus the underwriters demonstrated that the sanction imposed by Rule U-12F-2 was not sufficiently severe to cause all investment bankers to renounce their connections with issuers. ${ }^{\circ 0}$

This failure of the Rule has been minimized to some extent by the recent decision in the Dayton Pozver \& Light case, applying the Rule for the first time to prevent the payment of a fee to an affiliated underwriter. ${ }^{31}$ In

by "informal suggestion" when appropriate, relying for a sanction on its power under $\$ 7(d)(6)$ to disapprove a declaration if the terms and conditions of an issue or sale were found detrimental to the public interest. The ICC has used this informal method in the sale of terminal bonds by competitive bidding. Bonds Chicago Cinion Station, 239 I. C. C. 325 (1940). Finance Docket No. 12797. This type of regulation, though adapted to meet the special problem of interlocks, would be inadequate to cope with the larger problem of reasonable fees in non-aftiliate cases. It might be of great value in the development of a competitive bidding policy for stocks. See note $\mathbf{5}$ supro.

54. SEC Holding Company Act Release No. 1380, Dec. 28, 1938 (Commissioner Mathews dissenting). The Rule became effective March 1, 1939.

55. In Consumer's Power Co., 6 S. E. C. 444, 456 (1939), the Commissiun stated that it had "in substance" incorporated in $\Uparrow$ (a) (3) of the Rule the definition of affiliate set out in $\S 2(a)(11)(D)$.

56. Rule U-12F-2, $\int(\mathrm{a})$.

57. Id., If (d).

58. Normally the principal underwriter has the valuable privilege of selecting the other members of an underwriting syndicate.

59. Gulf States Util. Co., 5 S. E. C. 170 (1939); West Pemn Power Co., 5 S. E C. 376 (1939); Iowa Public Service Co., 5 S. E. C. 619 (1939).

60. The custom of reciprocity in the investment banking business is so firmly ingrained it seems probable that such affiliated principal underwriters distributed their farticipation among non-affliated members of the syndicate, selected by it, with the understanding that the favor would be returned in the funancing of future issues. Sce Hearings 11,529-11,534, 11,595-11,604.

61. SEC Holding Company Act Release No. 2654, Jfarch 28, 1941. 
February, 1940, the Dayton Power \& Light Co., a wholly-owned subsidiary of Columbia Gas and Electric Co., one of the sub-holding companies in the United Corporation system, filed an application to issue and sell bonds in the amount of $\$ 25,000,000$ to a syndicate headed by Morgan, Stanley \& Co. The latter was to receive a management fee and to underwrite well over five per cent of the issue. ${ }^{62}$ To test the efficacy of Rule U-12F-2 the Commission initiated proceedings ${ }^{63}$ to determine whether Morgan, Stanley \& Co. was an affiliate of Dayton Power and Light Co., and thus barred by the Rule from receiving any underwriting fee. To prove affiliation the Commission had to demonstrate that Morgan, Stanley \& Co. and J. P. Morgan \& Co. were in fact one, ${ }^{64}$ and that Morgan, Stanley \& Co., through J. P. Morgan \& Co., was in a position to assert a controlling influence ${ }^{05}$ over the financial policies of companies within the United Corporation system, founded by J. P. Morgan \& Co. and Bonbright \& Co. to protect investments in utility securities and to secure the profits of utility financing. ${ }^{10}$ It is common knowledge that since the creation of United Corporation, J. P. Morgan \& Co. and Morgan, Stanley \& Co. have monopolized the financing of companies within the system. ${ }^{67}$ Yet it has taken the SEC thirteen months to make a finding of affiliation between Morgan, Stanley \& Co. and Dayton Power and Light Co. In part this delay may have been due to the evidentiary difficulties involved in proving affirmatively an absence

62. Dayton Power \& Light Co., 6 S. E. C. 787 (1940).

63. Previously, in connection with Consumer Power Co., 6 S. E. C. 444 (1939), the Commission had started proceedings to determine whether Morgan, Stanley \& Co. and Consumer's Power Co. were affiliates. The Dayton and Constmer's cases were alike in that they both presented the question of an interlock through United Corporation. After the Dayton proceedings were begun, those in the Consumer's case were abandoned.

64. As a result of the Banking Act of $1933 \mathrm{~J}$. P. Morgan \& Co. withdrew from the underwriting business, and in 1935 Morgan, Stanley \& Co. was formed as an underwriting firm. After the Dayton case, proceedings under the Trust Indenture Act of 1939 were commenced by the Commission to determine whether there was a control relationship between Morgan, Stanley \& Co. and J. P. Morgan \& Co. which would disqualify the latter from being a trustee in an issue underwritten by Morgan, Stanlcy it Co. These proceedings, however, never reached a conclusion since J. P. Morgan \& Co. resigned the trusteeship. N. Y. Times, Jan. 23, 1941, p. 29, col. 8. For evidence of the identity of J. P. Morgan \& Co., and Morgan, Stanley \& Co., see Hcarings 12,049-12,086. See also SEC Holding Company Act Release No. 2654, March 28, 1941.

65. As defined in $\$ 2(a)(11)(D)$.

66. T. S. Lamont of J. P. Morgan \& Co., discussing certain investment trusts, stated that their "purposes . . . are in a way similar to the one proposed (United Corp.) in that ... their purpose is obviously to insure continued control by the bankers ..." Hearings 12,070 . However, United Corp. has filed a plan under $\$ 11$ (e) by which United will not vote any of the utility securities held by it and will divest itself of its holdings as soon as an opportunity is presented, thus hoping for a declaration it is not a holding company under $\$ 2$ (a) (7). N. Y. Herald-Tribune, March 6, 1941, p. 29, col. 6.

67. For an account of financing of the United system see Brief for SEC Pub. Util. Div., pp. 45-59, Matter of Dayton Power \& Light Co., 6 S. E. C. 787 (1940); SEC Holding Company Act Release No. 2654, March 28, 1941. 
of arm's-length bargaining where no explicit control exists; ${ }^{69}$ it may also be explained by challenges as to the legality of Rule U-12F-2 in setting up a new definition of affiliate in contravention of the language of the Act. ${ }^{\text {co }}$ A strong indication of the administrative impracticability of Rule U-12F-2, the belated decision is nevertheless significant, for if it is upheld by the courts it presages eventual elimination of the interlocks which the SEC has attacked. ${ }^{70}$ However, neither the Dayton decision nor other experience with the Rule provides any assurance that underwriting fees will be reasonable or that competitive conditions will be maintained in transactions involving affiliates. ${ }^{71}$ These limitations, in conjunction with the failure of direct supervision of underwriting fees, indicate that other methods of regulation should be adopted. The most desirable alternative is a system of competitive bidding.

Competitive bidding. For purposes of public utility finance, competitive bidding involves an administrative requirement that a utility request sealed bids in the sale of an issue of bonds, and that the bids submitted be listed in the utility's application for leave to sell the issue to a banking group at a price named in the application. ${ }^{22}$ In form there is no compulsion to sell to the highest bidder, but in practice administrative supervision and the fiduciary duty owed by the corporation and its management to the stockholders operate to assure the acceptance of the highest bid, ${ }^{73}$ provided the bidder is financially responsible, and not unsatisfactory for other reasons. In any event, com-

68. At present J. P. ATorgan \& Co. possesses only $1 / 2$ of $1 \%$ common stock interest in United, and it is not otherwise represented by directors or officers. For a view of the evidentiary problems in the Dayton case see briefs in Matter of Dayton Power \& Light Co., 6 S. E. C. 787 (1940).

69. In essence the argument is simple: Rule U-12F-2 sets up a new definition of affiliate in violation of the language of $\S 2(a)(11)(D)$ and $\$ 2(b)$. The statute declares an affiliation exists when there "is liable to be such an absence of arm's length bargaining" as to require application of the Act. The Rule omits the restrictive word "such," thus attempting to confer powers broader than those conferred in the statute. Also, by permitting a finding of affiliation to be made and applied in the same proceeding, the Rule evades the language of $\$ 2(b)$ requiring that 30 days must elapse before enforcement of a finding of affiliation made under $\$ 2(a)(11)(D)$.

70. For example: SEC Holding Company Act Releases No. 1911, Feb. 2, 1940; No. 1941, Feb. 26, 1940; No. 2259, Aug. 23, 1940. However, the only decision on affiliation under the rule is the Dayton case.

71. The Public Utilities Division and the SEC have conceded the inadequacy of the Ruie. Pub. Util. Report 9; SEC Sixtr Annual Report (1941) 35. See also note 60, sipra

72. For various forms of this procedure see PUB. UTIL. REront 45; Regulations Relative to Bids of Carriers, 56 I. C. C. 847 (1920); Western Maryland Equipment Trust, Series D, 111 I. C. C. 434 (1926) ; Public Service Co. of N. H., 17 N. H. S. P. C. R. 367 (1935) ; Miass. Ann. Laws (1940) c. 164, §15; 12 P. U. R. (:.s.) 9 (1936).

73. The highest bidder is the bidder offering the greatest percentage of par at the lowest interest rate, i.e., the lowest cost of money to maturity. There are a very few instances in which a bid other than the highest has been accepted. See Por. Urin. REPORT C-31. 
petitive bids provide commissions with suitable evidence by which to juclge the propriety of prices to be received and fees to be paid.

Although it is occasionally urged that the SEC lacks authority to impose a competitive bidding requirement, even a cursory examination of the broad powers conferred by the Holding Company Act demonstrates that a competitive bidding rule is not likely to stumble on the athority hurclle. ${ }^{\text {74 }}$ More important than the authority issue is the inquiry whether competitive bidding will actually produce the desired reforms. It has alreacly been demonstrated that other methods of regulation have failed - because they bogged down in procedural mires and because they did not attack the fundamental problem: elimination of the customs and agreenents which make the system of private negotiation non-competitive. Competitive bidding would achieve this objective by destroying the motive for banker influence, and by relieving management of the pressures which have caused it to shtul competition. When sealed bids must be submitted, and the highest bid will be accepted, it is apparent that the traditional underwriter is not certain to get the business. Money and effort expended to influence corporate financial policy will no longer assure the existence of a banking monopoly, and management on its part will be forced to assume an independent position divorced

74. It seems clear that the SEC has the power to adopt the proposed rule. Sections 6(b) and 7(a) (2) of the Holding Company Act grant power to the SEC to recquire that a declaration (application) to issue securities shall include "such additional information, in such form and detail . . . as the commission may . . . prescribe as . . . appropriatc in the public interest or for the protection of investors and consumers." A competitive bidding rule would come within this language because competitive bids furnish informition of value in passing on declarations. The Maine Commission has found atuthority to require competitive bidding in similar language of the Maine Statute. Communication to Yale L. J. from Pub. Util. Com. of Maine; ME. Rev. Stat. (1930) c. $62 \S 41$.

A competitive bidding rule can also be sustained under the general rule-making power of $\S 20(a)$, supplemented by $\S 7(d)(6)$, providing that the terms and conditions of an issue or sale be not detrimental to the public interest or to the interests of investors and consumers, and by the language in $\S 6(\mathrm{~b})$, stating that the Commission shall on certain occasions grant an exemption from $\$ 7$ subject to such terms and conditions as it deems necessary or appropriate to protect the public interest. Since competitive bidding reduces financing charges, it is in the "public interest" within these sections of the Act, as well as the definition of "public interest" in the preamble.

The ICC, the Federal Power Commission, and the commissions of the District of Columbia, Indiana, Maine, Missouri, New Hampshire and Pennsylvania, operating under statutes no broader than the Holding Company Act, have required competitive bidding without incurring challenge or judicial disapproval. For the orders sec $111 \mathrm{I}$. C. C. 434 (1926) ; FPC Order No. 62 (1939); 12 P. U. R. (N.s.) 9 (1936); P. U. R. 1918A, 325; P. U. R. 1928C, 354; General Order Missouri Commission (1938) ; 17 N. H. P. S. C. R. 268 (1935); 6 P. U. R. (N.s.) 22 (1935). For the statutes see 41 STAT. 494, 49 U. S. C. $\$ 20$ (a) (1934); 49 Stat. 858,16 U. S. C. $\$ 825($ h) ; D. C. Code (1929) tit. 26, $\$ \$ 54,97,98,102$; Ind. Stat. Ann. (Burns, 1940) §54-505; Mo. Star. AnN. (1940) p. 6618, § 5194; N. H. Pub. Law (1926) c. $241 \$ 3$; PA. Stat. (Purdon, 1936) tit. 66, $\$ 202$. 
from reliance on any financial interest. ${ }^{\mathrm{T}}$ Fear of disagreeable consequences which may prevent management from taking the initiative in introducing competitive bidding will no longer be operative, ${ }^{76}$ and experience shows that a minimum of administrative supervision will be required, since the presence of competition tends automatically to insure reasonable fees and prices. ${ }^{77}$

The pragmatic test of actual use demonstrates that the advantages of competitive bidding are not illusory. Thus, in the period from 1920 to 1926, when the ICC did not require competitive bidding for either equipment trust certificates or railroad bonds, the average underwriting fees for the two classes of securities were approximately 2.08 and 3.41 points respectively. ${ }^{78}$ Since 1926, equipment trust certificates have been sold on a competitive basis, and underwriting fees have averaged .68 and 2.42 points respectively, ${ }^{70}$ fees in equipment trust financing being reduced by two-thirds while those charged in bond issues declined but one-third. The recent Report of the Public Utilities Division of the SEC offers additional corroboration. Fourteen utility bond issues sold on a competitive basis were compared with 159 bond issues sold through private negotiation. Underwriting fees averaged 1.24 points in the competitive issues and two points in the negotiated issues. ${ }^{80}$ The Report establishes, in addition, that a system of competitive bidding does not nullify reductions in fees by increasing the "other expenses" involved in selling the securities, such as the cost of preparing and printing registration statements and indentures, and payment of legal fees. ${ }^{82}$

Beyond increasing the issuer's net proceeds by the amount of the reduction in underwriting fees, competitive bidding further diminishes financing costs by increasing the percentage of par received by the issuer, by reducing the interest rate, or by both. ${ }^{82}$ Competition automatically tends to drive prices

75. Management is not always enthusiastic. See Northern States Power Co., $f$ S. E. C. 728,738 (1939).

76. See ERnst, Too Brg (1940) 195.

77. Undoubtedly this is one of the most important advantages of competitive bidding. For an example of its smooth operation see 17 N. H. P. S. C. R. 367 (1935); 18 N. H. P. S. C. R. 6, 48 (1936) ; see PUB. UTIL. Report C-34. Likewise, in the sale of equipment trusts, competitive bidding has been an effective administrative device. See remarks of Senator Truman, N. Y. Times, Feb. 7, 1941, p. 29, col. 6. Cf. FPC Release No. 1383, Jan. 8, 1941.

78. The figures are reported in Elgen, supra note 8, at 725. In 1922 the ICC held a hearing on competitive bidding. Compare Bonds Chicago Union Station Co., 86 I. C. C. 529 (1924) with Bonds Chicago Union Station Co., 94 I. C. C. 177 (1924). See LocrIIN, REG. SECURITY IsSUES BY ICC (1927) 114-116. Later the ICC required competitive bidding for equipment trust certificates. IVestern Maryland Equipment Trust, 111 I. C. C. 434 (1926).

79. See note 78 supra.

80. Pub. Util. Report C-22.

81. Id., C-25.

S2. Waterman, Finanial Fence Mending in 1936 (1937) 19 P. U. Font. 211, 218. Robert R. Young, director of Chesapeake \& Ohio R. R., has declared that the Cincin- 
up and the custom of slightly underpricing an issue, practiced in negotiated sales, disappears under competitive bidding. There are no statistics showing the amount of saving actually involved, since securities issued under the identical conditions needed to make fair comparisons cannot be found; yet actual experience with competitive biddling in Massachusetts and New Hampshire is evidence of its value in this respect. In Massachusetts ${ }^{83}$ anntal reports of the Department of Utilities ${ }^{84}$ indicate that under competitive bidding the companies have sold their bonds at unusually ${ }^{85}$ good prices and interest rates. Although the Department has recommended the repeal of competitive bidding laws as to certain stocks, ${ }^{86}$ it has conspicuously failed to make such recommendations with respect to utility bonds, where the system has been eminently satisfactory. Analogous experience in New Hampshire in requiring competitive bidding for utility bonds offers additional proof. ${ }^{87}$

Similarly, experience in several jurisdictions bears witness that competitive bidding, in addition to the reduction of costs, eliminates monopoly in investment banking by preventing any one banking group from securing a dominant position in a corporation's financing. Twenty-four of the nation's large railroad systems have customarily sold their securities through certain bankers who monopolized this financing. ${ }^{88}$ Since the 1926 requirement that

nati Union Terminal Co. saved $\$ 1,500,000$ by selling its bonds through competitive bidding in 1939. In 1941 the Terminal Co. plans to sell another block of bonds through competitive bidding. N. Y. Herald-Tribune, March 5, 1941, p. 29, col. 4.

83. Competitive bidding is required by statute. Mass. ANN. Laws (1940) c. 164, $\$ 15$. The statute was enacted to insure that utilities would sell their securities on the best terms obtainable. See 34tr Ann. Rep., Mass. Bonrd of Gas \& Elec. CommissionERS (1919) 9. For a review of Massachusetts reguiation of utility securities see BAnNes, Public Utility Control in Massachusetts (1930) c. II.

84. For the years following the enactment of the competitive bidding statute the Department of Utilities was able to report that the companies affected were selling their securities advantageously. ANn. Rep. Mass. Dep't of Utilities (1921) 18; id. (1922) 13.

85. Boston Edison Co. recently sold a $\$ 53,000,000$ bond issue through competitive bidding at a cost of money of $2.58 \%$, reputed to be the lowest price ever paid by a utility. See PUB. UtTIL. REPoRT, C-37.

86. Ann. Rep. Mass. Dep't Utilities (1920) Pt. I, 30.

87. See Public Service Co. of New Hampshire, 17 N. H. P. S. C. R. 268 (1935); Public Service Co. of New Hampshire, 17 N. H. P. S. C. R. 367 (1935).

88. Northern Pacific Equipment Trust, 99 I. C. C. 164, 166 (1925). Consider also Chairman Eastman's dissents on the subject of competitive bidding and banking monopoly in N. Y. Central Equipment Trust, 99 I. C. C. 121, 124 (1925). Pennsylvania Equipment Trust, Series D, 111 I. C. C. 241,244 (1926) ; control of Louisiana \& A. Ry. Co., 150 I. C. C. 477,491 (1929). Cincinnati Union Terminal Securities, 166 I. C. C. 499, 500 (1930). See also dissent of Commissioner Scott, 1 Fed. Power Comm. Rep. 794, 797 (1940). For a survey of ICC competitive bidding policy see 3-A Suarfanan, TuE INTERSTATE COMMERCE Commission 564-577. The ICC is still prepared to consider competitive bidding for bonds if the credit standing of the issuer is as high as is usually the case with public utilities. See Finance Docket No. 12,700 for Louisville \& Nashville R. R. Bonds, 236 I. C. C. 680 (1940). 
equipment trust certificates be sold through competitive bidding, however, the regular bankers have ceased to handle these securities. ${ }^{80}$ In contrast, bonds, with one exception, have been continually sold through the customary monopolistic banking channels. ${ }^{00}$ Significantly, the exception occurred when the Chesapeake \& Ohio Railroad, which usually sold its securities through J. P. Morgan \& Co. or Morgan, Stanley \& Co., put up an issue for competitive bidding and sold it through a different syndicate. ${ }^{01}$ Furthermore, the Report's analysis of bonds sold on a competitive basis indicates that victory goes to the highest bidder rather than to the traditional underwriter. ${ }^{22}$ Hence, competitive bidding, though not specifically directed at the problem of interlocking directorates and underwriter ownership of an issuer's stock, serves as an effective insulator against these forms of control by insuring the maintenance of arm's-length bargaining in spite of such relationships. The proposed system is to some extent an exemplary substitute for the unfortunate Rule U-12F-2, which has not been altogether successful in producing competition or in severing monopolistic affiliations.

Competitive bidding, however, has not been without its critics, who argue that it will injure investors and issuers as well as underwriters and dealers. ${ }^{03}$ It is argued that by eliminating the regular banker who may insist that protective provisions be inserted in indentures, investors will suffer. But a major cause for creation of the SEC's powers under the Trust Indenture ${ }^{\text {at }}$ and Holding Company Acts was the failure of bankers to protect the interest of the investing public; ${ }^{95}$ and these critics have not suggested the SEC will not provide the necessary safeguards. Likewise, the contention that competitive bidding will cause losses to purchasers by forcing security prices to levels unsustainable after the public offering, is of dubious validity. The argument implies that it is not in the public interest for utilities to sell their securities on the best terms obtainable - the antithesis of the premise supporting regulation of utility finance. Furthermore, overpricing is likely to be

89. Moody's Steakr Ratroads (1929).

90. Moody's Steaxi Railroads (1939).

91. The new syndicate was headed by Halsey, Stuart \& Co. and Otis \& Co. See Chesapeake \& Ohio R. R. Bonds, 230 I. C. C. 483 (1938), and testimony before the Senate Interstate Commerce Committee, Sex. Rep. No. 25, Pt. 16, 76th Cong., 3d Sess. (1940) 19.

92. Pub. UTII. Report C-31. The financing of A. T. \& T. in the years 1898-1905, when it sold securities through competitive bidding, demonstrates that the banking monopoly which has characterized the company's financing since 1906 did not exist during that time. Hearings 11,830-11,845. Danielan, A. T. \& T. (1939) cc. III, IV. Attempts to break the J. P. Morgan \& Co. (Morgan, Stanley \& $\mathrm{Co}$.) monopoly have failed. Witness President Gifford's refusal to accept a competitive bid from Halsey, Stuart \& Co. in the 1935 Illinois Bell Telephone issue. Hearings 11,935-11,941.

93. See note 6 supra.

94. 53 SтAт. 1149 (1939), 15 U. S. C. $\$ 77 a z a$ (Supp. V 1939).

95. See, generally, FTC Report on Utility Corposatrois, Sen. Doc. No. 92, Part 72-A, 70th Cong., 1st Sess. (1935); SEC Report, Pt. VI (1936). 
curtailed by so-called buyers' strikes, and in any case the supposed injury to individual investors is largely imaginary: the buyers of utility bonds are mainly institutional investors purchasing for yield to maturity without regard for short term price fluctuations. Nor is it likely that issuers will be injured by losing the advice of a regular banker or his assistance in preparing registration statements and indentures. Utility management is able to formulate its own financial policy, ${ }^{96}$ and although an independent adviser can be employed if necessary, ${ }^{07}$ setting up registration statements and inclentures is no longer difficult. ${ }^{98}$

Because competitive bidding involves changing the present system, it has been urged that the intricate machinery laboriously devised for the marketing of utility bonds will be upset.90 The experience of Massachusetts and New Hampshire indicates, however, that competitive bidding need not interfere with an issuer's time schedule or penalize underwriters by lengthening the period during which they are committed but are unable to market the securities for lack of commission consents. ${ }^{100}$ It is also unlikely that the success of competitive bidding will be limited to small issues or favorable market conditions. Large issues sold on a competitive basis have so far been suc-

96. In practice management decides how and when new securities shall be issucd even before going to a banker. Furthermore, most of the holding company systems cmploy experts whose services are available at a minimum charge. In sales of equity securities, however, which are less simple than refunding bond issues, investment bankers may still furnish invaluable aid. Furthermore, the recent El Paso decision, SEC .Holding Company Act Release No. 2530, Feb. 3, 1941, indicates that there may be considerable stock financing in the future. See note 53 supra.

97. This alternative is subject to criticism in that the arm's-length bargaining question might be reopened if the independent adviser was potentially affiliated with the issuer. Furthermore, by increasing the expenses of an issue it might detract from the economic advantages of competitive bidding. However, there is slight need for an independent adviser at present. See note $96 \cdot$ supra.

98. Setting up an issue was an onerous task in early issues under the Securities and Holding Company Acts. To avoid the liabilities imposed by the Securities Act underwriters had to investigate issuers carefully. However, the necessary basic work has now been done and preparation of documents for a new issue is but a matter of bringing old ones up to date. Furthermore, under competitive bidding as well as under the present system of private negotiation, issuers contract to indemnify underwriters against liabilities arising from the Securities Act. In New Hampshire, where the issuer draws up the indenture and tentative registration statements, neither issuer nor underwriters have found the procedure impracticable.

99. The process is complex because, in addition to authorizations from the SEC acting under the Securities, Holding Company and Trust Indenture Acts, it is necessary to obtain approvals from commissions in the states where the utility is incorporated, or operates, and perhaps of the Federal Power Commission as well. All these consents must be secured without upsetting the planned time schedule.

100. For several years underwriting contracts have contained "market out" clauses which relieve an underwriter of obligation in case of market changes. Such clauses can also be used when an issue is sold through competitive bidding. 
cessful ${ }^{101}$ and depression experience shows that a favorable market is not indispensable.

Nor is it likely that competitive bidding will be saljotaged by a concerted refusal to submit bids, ${ }^{102}$ since arrangements to chill bidding are illegal and may even invoke the sanctions of the Sherman Act. ${ }^{103}$ Furthermore, the activities of underwriting houses like Halsey, Stuart \& Co. and Otis \& Co., which are eager to submit competitive bids, provide a practical guarantee that other bankers will not desire to risk losing the business to them by refusing to compete. ${ }^{104}$

Though not an open sesame to financial democracy through which the "little fellow" can rise to prominence and destroy the hegemony of the large underwriters, ${ }^{105}$ competitive bidding would achieve substantial reforms. By forcing large financial institutions to compete among themselves it would reduce underwriting fees, end banker monopoly, and open the luusiness to a few bankers now squeezed out by the superior capital, prestige, and experience of the established investment houses. In any event, it seems clear that high grade, eminently saleable, utility bonds should be sold on a competitive basis, thus terminating a system of private monopoly in the financing of corporations in which the public has a vital interest. ${ }^{100}$

J. K. BusBY $T$

101. See note 85 supra; Pub. UTrL RePORT, C-34. In the few cases where an issue might be so large that only one syndicate would submit a bid, no serious difficulty need .exist, for the issue could be subdivided and sold in blocks.

102. In practice there is free competition. For figures on number of bids and syndicates see Pub. UtIL. Report C-34, C-37. But see Bonds Chicago Union Station Co., 239 I. C. C. 325 (1940), in which 107 invitations to bid were sent out and only one received. But issue was sold to regular bankers by private negotiations at a price higher than that named in bid. The ICC implied its disapproval of this "sit-down strike" by capital. Finance Docket No. 12,797; Hearings 11,807-11,817. See note 20 supra.

103. Agreements to interfere with free competitive bidding are against public policy. See Tate v. Gould, 175 Ark. 305, 299 S. W. 24 (1927); Finley Co. v. Standard Asphalt Co., 104 Fla. 126, 139 S. 795 (1932). Such activities may be tortious. Restatevereit, ToRTs (1939) $\$ 765$. Or they may constitute a violation of the Sherman Act. United States v. Addystone Pipe \& Steel Co., 85 Fed. 271 (C. C. A. 6th, 1898), off'd, 175 U. S. 211, 244 (1899). Furthermore, an agreement to restrain competition may be inferred from the acts of the parties; an express agreement is unnecessary. Interstate Circuit v. United States, 306 U. S. 208, 221 (1939).

104. See notes 4,91 supra. If it should appear that a competitive bidding requirement was being flouted, issues could be sold directly to insurance companies, thus nullifying the effectiveness of understandings not to compete. Consider also the role of the RFC in railroad financing, where it has frequently intervened to insure that private bankers were buying railroad securities on reasonable terms. Just recently the RFC purchased a large issue of municipal bonds when it seemed that underwriters were taking advantage of their position to require too high an interest coupon. See U*ited STAtes NEws, Mar. 14, 1941, p. 35.

105. See Eaton, Financial Democracy (1941) 8 U. of Cri. L. Rev. 195.

106. See note 35 supra. See also letter of 1905 of Lee, Higginson \& Co. to A. T. \& T. recommending that the company take advantage of its high credit standing by selling its securities through competitive bidding. Hearings 11,830.

$\dagger$ Third Year Class, Yale Law School. 